\title{
Alarm symptoms, risk factors for digestive tract cancer and readiness to participate in an endoscopic screening program
}

\author{
Objawy alarmowe, czynniki ryzyka wystapienia raka przewodu pokarmowego \\ i gotowość do udziału w endoskopowych badaniach przesiewowych
}

\author{
Bartłomiej Antoni Ziółkowski, Agnieszka Pacholec, Jacek Teodor Muszyński \\ Department of Gastroenterology and Metabolic Diseases, Medical University of Warsaw, Poland
}

Prz Gastroenterol 2013; 8 (2): 108-114

DOI: $10.5114 / p g .2013 .34836$

Key words: colorectal cancer, prevalence, public awareness.

Słowa kluczowe: rak jelita grubego, chorobowość, świadomość społeczna.

Address for correspondence: Bartłomiej Antoni Ziółkowski MD, PhD, Department of Gastroenterology and Metabolic Diseases, Medical University of Warsaw, 1 A Banacha St, $02-097$ Warsaw, Poland, phone: +48 2259918 38, fax: +48 501721 626, e-mail: bziolkow@gmail.com

\begin{abstract}
Introduction: There are no data available on the prevalence of digestive tract alarm symptoms or reflecting the readiness of the Polish population to undergo endoscopic screening for colorectal and other gastrointestinal cancers.

Aim: To determine the prevalence of alarm symptoms, readiness levels to undergo endoscopic screening for cancer and to identify decision-making factors.

Material and methods: Demographic and anthropometric data, alarm symptoms, nutritional habits, alcohol use, smoking, concomitant diseases and a family history of cancer were studied in an interview in a random sample from a middlesized city.

Results: A total of 850 people were interviewed between 2002 and 2009. Alarm symptoms (weight loss $>10 \mathrm{~kg}$, abdominal pain waking the patient up at night, persistent vomiting, dysphagia, blood in stool, constipation < 12 months, diarrhea $>1$ month, anemia) were present in $15 \%$ of participants. Fiftytwo percent of those with alarm symptoms had not been diagnosed before the survey, $38 \%$ had never had and still refused diagnostic endoscopic procedures. Less than $20 \%$ of all respondents declared their willingness to be screened. Readiness was significantly higher in males, diabetics, respondents with previous endoscopy and those with a family history of neoplasm, and it increased with the level of education. Smokers more often refused screening procedures. There was no significant increase in readiness for screening over the period studied.

Conclusions: Considering how small a proportion of respondents declared themselves ready for endoscopic cancer screening, even those at increased risk, more efforts should be made
\end{abstract}

\section{Streszczenie}

Wstęp: Brakuje danych dotyczących gotowości polskiej populacji do poddawania się endoskopowym badaniom przesiewowym. Nie jest także znana częstość występowania objawów alarmowych związanych z przewodem pokarmowym.

Cel: Ustalenie poziomu gotowości populacji polskiej do poddania się endoskopowym badaniom przesiewowym, rozpoznanie czynników wpływających na tę decyzję oraz ustalenie częstości występowania objawów alarmowych.

Materiał i metody: Ankieta przeprowadzana wśród losowo wybranych mieszkańców miasta o średniej wielkości, zawierająca pytania dotyczące danych demograficznych, antropometrycznych, objawów alarmowych, zwyczajów żywieniowych, stosowania używek, chorób wspótistniejących oraz rodzinnych wywiadów raka.

Wyniki: W latach 2002-2009 przeprowadzono ankietę wśród 850 osób. Objawy alarmowe, definiowane jako chudnięcie powyżej $10 \mathrm{~kg}$, ból brzucha wybudzający pacjenta w nocy, uporczywe wymioty, dysfagia, krew w stolcu, zaparcie poniżej 12 miesięcy, biegunka powyżej miesiąca i niedokrwistość, rozpoznano ogółem u 15\% uczestników badania. W momencie przeprowadzania eksperymentu 52\% osób z objawami alarmowymi nie miało przeprowadzonych diagnostycznych badań endoskopowych. W tej grupie niediagnozowanych pacjentów z objawami $38 \%$ nie zamierzało się w ogóle poddać diagnostyce. Mniej niż 20\% ankietowanych wyraziło chęć poddania się profilaktycznemu badaniu endoskopowemu. Istotnie częściej byli to mężczyźni, osoby wykształcone, chorzy na cukrzycę, osoby z rodzinnymi wywiadami chorób nowotworowych oraz pacjenci, którzy w przeszłości mieli już wykonane jakieś badanie endoskopowe. Palacze częściej nie godzili się na ba- 
to raise public awareness about the importance of early detection screening. dania przesiewowe. W obserwowanym okresie nie stwierdzono istotnego wzrostu gotowości do poddawania się endoskopowym badaniom przesiewowym.

Wnioski: Z uwagi na mały odsetek respondentów deklarujących gotowość do poddania się endoskopowym badaniom przesiewowym, zwłaszcza wśród osób ze współistniejącymi czynnikami ryzyka, należy położyć większy nacisk na podnoszenie świadomości społecznej odnośnie do znaczenia wczesnego wykrywania raka.

Simultaneously with the implementation of the national colonoscopic screening program for colorectal cancer, an awareness campaign was launched in Poland seeking to educate the general public about CRC risk factors, symptoms and prevention methods. Respected medical officials have been invited to appear in the public media to promote CRC screening; hospitals and outpatient clinics display posters encouraging patients' participation in the program. The number of health-care centers involved in the colorectal cancer screening program increased from 6 to 40 during the first 4 years [5]. More than 100,000 participants are estimated to have undergone screening colonoscopy by the end of 2008 . Such spread of information should result in increased acceptance of endoscopy as a screening method. 10-19/100 000/year. The 5-year survival rate for both cancers in Poland is relatively small [1]. This seems to be caused not by high incidence, but late detection of both cancers, often in the metastatic stage [2]. In Western countries no screening is recommended for gastric cancer and appearance of alarm symptoms often indicates an advanced neoplastic process. In contrast to gastric cancer, colorectal cancer can now be detected earlier due to screening programs implemented in many countries. In Poland, the state-funded colorectal cancer screening program, with colonoscopy as a primary screening tool, is addressed to people aged 50-65 years, in good general health and without suspected CRC. People aged 40-49 years are also eligible for the program if they have a family history of colorectal cancer.

An estimated $12 \%$ to $77 \%$ of patients accept colonoscopy as a screening test for CRC in other countries [3, 4]. There are still no data available on the acceptance of endoscopic procedures as a screening tool in the Polish population. This information plus identification of factors influencing patients' readiness to be screened could help to tailor suitable interventions to decrease mortality from both gastric and colorectal cancer.

The problem of colorectal cancer, now the second most common cause of death from cancer in Western countries, was not adequately addressed in the public media in the $20^{\text {th }}$ century. This seems to be the reason why many patients still underestimate the risk of this condition [4].

\section{Aim}

The aim of this study was to assess the prevalence of alarm symptoms, as well as to establish the proportion of some diagnostic procedures before the study. Moreover, we aimed to assess readiness to undergo endoscopic diagnostic procedures in people with uninvestigated alarm symptoms as well as to determine the proportion of the population without symptoms suggesting malignancy ready to participate in endoscopic screening for cancer. Some factors influencing this decision were also studied. The last question to answer was if the public awareness campaign increased readiness for endoscopic screening over the period studied.

\section{Material and methods}

This study was part of a larger project aiming at establishing the prevalence of abdominal symptoms in the Polish population [6]. A random sample of 1,100 residents was drawn from the registry of the population of the city of Otwock (43,000 inhabitants). Those individuals who agreed to participate in the study met the inclusion criteria if they were over 18 years old, mentally competent to be interviewed, able to understand, write and read in Polish. Out of the 1,100 inhabitants, 182 (17\%) declined to take part in the study and 69 (6\%) could not be contacted or did not meet the above criteria. The rerespondents with alarm symptoms who had already had 
Table I. Age distribution of respondents

Tabela I. Wiek respondentów

\begin{tabular}{lcccccc} 
& Respondents & \multicolumn{2}{c}{ Male } & \multicolumn{2}{c}{ Female } \\
\hline Age [years] & Number & Percent & Number & Percent & Number & Percent \\
\hline $18-29$ & 87 & 11 & 28 & 8 & 59 & 11 \\
\hline $30-39$ & 163 & 19 & 62 & 18 & 101 & 19 \\
\hline $40-65$ & 520 & 61 & 220 & 64 & 300 & 58 \\
\hline$\geq 66$ & 80 & 9 & 30 & 8 & 50 & 9 \\
\hline Total & 850 & 100 & 340 & 100 & 510 & 100
\end{tabular}

maining 850 respondents, aged $21-76$ years, were interviewed by trained interviewers. The study took 8 years between 2002 and 2009. Each participant answered an anonymous questionnaire including questions regarding demographic and anthropometric data, alarm symptoms, concomitant diseases, a family history of cancer, as well as nutritional habits, alcohol and tobacco use. There was also a question concerning readiness to undergo endoscopic screening for cancer (gastro- or colonoscopy). Respondents declaring their interest were asked to leave their contact information to be qualified for screening. The collected data were inserted into a Microsoft Office Excel 2007 database and then statistically analyzed using the methods of approximate confidence intervals, confidence intervals and one-sided confidence intervals, as well as confidence intervals for percentage non-conforming. All the intervals were constructed at $1-\alpha=0.99$ confidence level. Hypothesis verification procedures were applied: the null hypotheses of equality of two percentages (an approximation test), and the null hypotheses of no relationship between the measured features (a $\chi^{2}$ test for independence). The Yates' correction was used in $2 \times 2$ tables. All the null hypotheses were verified at a significance level of $\alpha=0.01$.

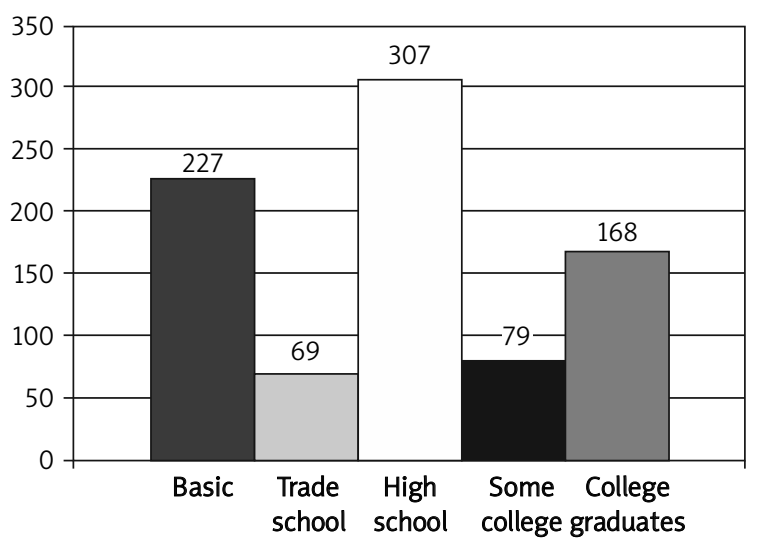

Fig. 1. Education of respondents

Ryc. 1. Wyksztatcenie respondentów

\section{Results}

Three hundred and forty men and 510 women were interviewed (men 40\%, women 60\%). Respondents eligible for screening procedures (age 40-65) comprised $61 \%$ of the group $(n=520)$. Details are given in Table I. All respondents were white, 63\% were married, $67 \%$ were professionally active. Most respondents had completed at least high school education (Figure 1). Overweight respondents (BMI $25-29.9 \mathrm{~kg} / \mathrm{m}^{2}$ ) comprised $35.8 \%(n=304)$, while obese $\left(\mathrm{BMI}>30 \mathrm{~kg} / \mathrm{m}^{2}\right)$ comprised $14.5 \%(n=123)$ of the group. Obesity was more common in men (men 19.4\%, women $11.2 \%, p<0.01$ ). Diabetes (of any type) was present in $14.6 \%$ of respondents $(n=124)$. $36.1 \%(n=307)$ of respondents smoked cigarettes, the habit being more common in men (men 50\%, women $27 \%, p<0.01)$. Former smokers comprised $14.2 \%$ of the group $(n=121)$. The average declared alcohol consumption was 31.15 units/month (one unit defined as the equivalent of $10 \mathrm{~g}$ of pure ethanol, i.e. $20 \mathrm{ml}$ of vodka, $85 \mathrm{ml}$ of wine or $230 \mathrm{ml}$ of beer). $66.5 \%$ of men and $44 \%$ of women admitted alcohol consumption. Alcohol abuse, defined as regular drinking $>14$ units/ week for men and > 10 units for women, was found in 57 men and 10 women, which makes $7.9 \%$ of respondents.

Alarm symptoms (listed below) were recognized in 125 respondents, which makes $14.7 \%$ of the sample. Inadequate weight loss (> $10 \mathrm{~kg}$ ) was present in 11, dysphagia in 21, painful swallowing in 18, persistent vomiting causing weight loss in 13 , abdominal pain waking the patient up at night in 26 , and rectal bleeding in 36 respondents. Thirty-one participants complained of constipation for a period of $<12$ months, 7 respondents suffered from diarrhea lasting $>1$ month. Eleven respondents had been diagnosed with anemia before the study. Details are shown in Figure 2. Among the respondents with alarm symptoms, diagnostic endoscopic procedures had been performed in $48 \%(n=60)$. Fifty-two percent of respondents with alarm symptoms $(n=65)$ had not had any endoscopy before the study. Eighteen patients (14\%) from the uninvestigated group were will- 
ing to undergo endoscopy, while 47 (38\% of respondents with alarm symptoms) did not want any diagnostic procedures.

Out of the total of 850 respondents, 169 (20\%) declared their willingness to undergo endoscopic screening. This willingness did not increase with age.

Eleven percent of women $(n=58)$ and $33 \%$ of men $(n=111)(p<0.01)$ were willing to be screened by means of endoscopy. Willingness for screening was declared by $22 \%$ of respondents with $\mathrm{BMI}>30 \mathrm{~kg} / \mathrm{m}^{2}$ and $20 \%$ of respondents with $\mathrm{BMI}<30 \mathrm{~kg} / \mathrm{m}^{2}(\mathrm{NS}), 15 \%$ of smokers and $23 \%$ nonsmokers ( $p<0.01$ ), $13 \%$ of alcohol abusers, and $20 \%$ of respondents who did not abuse alcohol (NS). There were no statistical differences in eagerness for endoscopy screening among former smokers and nonsmokers. Neither were there any differences among tea or coffee drinkers. Twelve percent of respondents with elementary education, $13 \%$ of respondents with trade school education, $23 \%$ of respondents with high school education and $20 \%$ with college education (with or without a completed degree) declared themselves willing to undergo screening endoscopy $(p<0.01)$. Twenty-nine percent of medical professionals and $19 \%$ of respondents with a nonmedical profession (NS), 34\% of respondents with diabetes mellitus (DM, $n=42$ ) and 18\% of respondents without DM (non-DM, $n=127$ ) were interested in screening (DM: 34\%; non-DM: $18 \% ; p<0.01$ ).

One hundred and fifty-one respondents had had some endoscopy in the past. Out of those with a previous endoscopy, $37 \%$ declared their interest in screening. Out of 699 respondents who had never experienced endoscopy, only $113(16 \%)$ declared their willingness to participate in screening $(p<0.01)$. One hundred and ninty-one participants of the study had a family history of cancer. Out of this group, 63 people (33\%) were ready to undergo screening. Out of 659 respondents without a family history of cancer, only $16 \%(n=105)$ decided to participate in screening (33\% vs. $16 \% ; p<0.01$ ). Twentysix respondents (3\%) reported at least one case of colorectal cancer in their family. Among them, 58\% $(n=15)$ wanted to have an endoscopic investigation. A family history of gastric cancer was present in 21 respondents (2\%); 9 of them (43\%) wanted to undergo endoscopy.

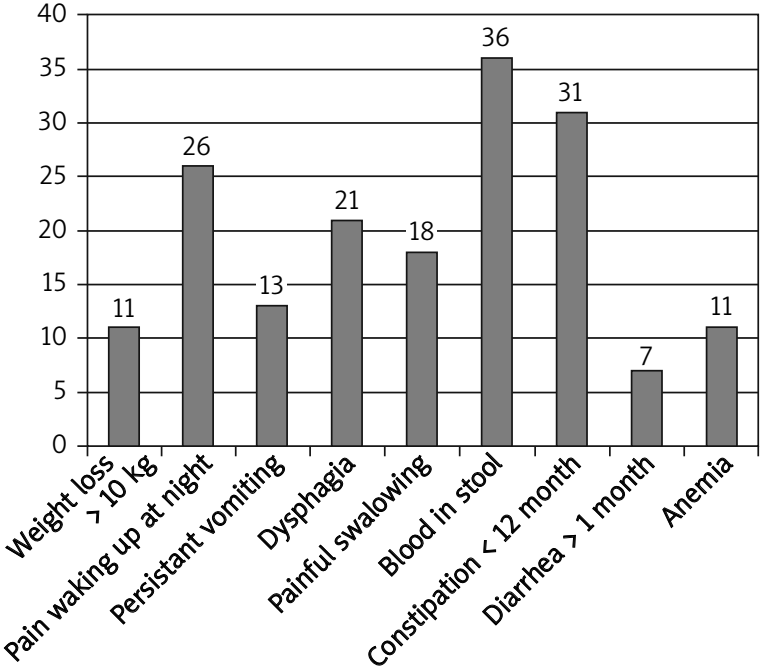

Fig. 2. Alarm symptoms in the sample (bars show number of respondents with the symptom)

Ryc. 2. Objawy alarmowe $w$ grupie badanej (kolumny przedstawiaja liczbę respondentów z objawem)

Even though this percentage is high it is not of statistical significance.

Since the numbers of respondents reviewed in consecutive years differed significantly, we used 2-year intervals to assess the tendency in readiness to be screened. Details are given in Table II. Based on the collected data, no significant trend was observed in the study sample as regards increasing readiness. The rates increased in consecutive periods, but the groups were not homogeneous and the time series was too short to show a statistically significant trend.

\section{Discussion}

Even though the target group for screening (40-65 years old) was represented by the highest number of respondents, comparing the data from our study with the results of a national census or epidemiological studies held in cardiology confirms that the studied sample was representative for Poland and reflected the actual social structure in terms of professional

Table II. Respondents interested in screening in the period studied (NS)

Tabela II. Odsetek osób zainteresowanych badaniami przesiewowymi w kolejnych latach (NS)

\begin{tabular}{lccc} 
Years & Number of respondents & Respondents interested in screening & Percent \\
\hline $2002-2003$ & 171 & 24 & 14 \\
\hline $2004-2005$ & 458 & 85 & 19 \\
\hline $2006-2007$ & 116 & 21 & 18 \\
\hline $2008-2009$ & 105 & 39 & 37 \\
\hline Total & 850 & 169 & 20
\end{tabular}


activity or the prevalence of risk factors such as obesity or smoking $[7,8]$.

It is estimated that alarm symptoms are quite often ignored or even concealed by the patients, due to the embarrassing character of the complaints. According to published data, up to $81 \%$ of Poles "feel embarrassed by bowel problems to such an extent that they delay seeing their doctor to discuss their symptoms". In other European countries, this embarrassment barrier is present in $39 \%$ to $91 \%$ of respondents [9].

In our study sample, almost $15 \%$ of respondents had alarm symptoms, a single symptom or a set of symptoms. Each of the investigated symptoms affected a small proportion of the study sample (from $0.8 \%$ in the case of chronic diarrhea to $4 \%$ for blood in the stool). According to some studies, in $10-11 \%$ of patients seeing their physicians for dyspeptic symptoms there is at least 1 alarm symptom which may be indicative of a serious disease [10, 11]. Most gastrointestinal cancers are asymptomatic until an advanced stage. Appearance of alarm symptoms usually means a late-stage and incurable condition. It is estimated that in the case of gastric cancer up to $27 \%$ of patients younger than 45 have no alarm symptoms at all [12-14]. On the other hand, a change in bowel habits does not necessarily mean colorectal cancer; an endocrine disease is one of the possible causes, and unusual bowel movements can also appear as a result of a change in one's diet, physical activity or medications used. A small amount of blood in the stool where there are no abnormalities in laboratory findings most often means hemorrhoidal bleeding. On the other hand, among patients with minimal rectal bleeding without other alarm symptoms, up to $30 \%$ may have a significant problem, around $7 \%$ may have cancer and $8 \%$ adenomas [15]. In Talley's paper, rectal bleeding (as the only symptom) was present in $13 \%$ of respondents and only $14 \%$ of them consulted a physician for this reason [16].

In our sample, more than half of the patients with alarm symptoms had not had any diagnostic procedures started before the study, and $38 \%$ of respondents with alarm symptoms refused diagnostic endoscopy even though their symptoms had never been investigated. This is a remarkable finding, possibly explaining the reason for late cancer detection in Poland. Therefore, it seems that improvement in cancer survival rates could be achieved by quite simple and cheap means: educating the general public that early detection usually saves lives.

Lifestyle, obesity, diabetes, cigarette smoking, and nutritional habits are well-known risk factors for cardiovascular diseases [17]. Similar correlations have recently been proved with respect to etiopathology of gastric and colorectal cancers. Nutritional habits, smoking, lack of physical activity and obesity may be contributing factors in the development of different digestive tract neoplasms. Age, genetic factors, smoking, diet rich in salt and preservatives, and Helicobacter pylori infection are well-known and obvious risk factors for gastric cancer. New data have recently been published suggesting that increased BMI, lack of physical activity, smoking and alcohol abuse are also contributing factors for gastric cancer [18-22]. Very similar factors are reported to cause CRC. It has already been proved that age, family history, diet rich in protein and fat, as well as lack of activity, obesity and impaired metabolism of glucose increase the risk for colorectal cancer [23-26]. Some data show that smoking may be another contributing factor [27, 28]. A prospective study by Hannan et al. showed an increased risk of developing CRC in both current and former smokers [29]. Moreover, Lieberman et al. suggested that heavy alcohol consumption increases the risk of finding advanced colonic lesions in men [28].

Stomach cancer is the second leading cause of cancer-related deaths worldwide. In the year 2000, CRC incidence took first place in Europe, with 304,687 new cases as compared to 301,090 new cases of lung cancer. The incidence of both colorectal and gastric cancer in Poland is still quite high and survival very low $[30,31]$. Survival rates could be improved by early detection screening. In our study, readiness to undergo screening endoscopy (upper or lower) was declared by $20 \%$ of respondents. According to different surveys and depending on the population studied, colonoscopy as a screening test is accepted by $12 \%$ to $77 \%$ of respondents. This number depends on the gender of respondents, having a regular primary care physician, and the level of health awareness, as well as some other factors such as acceptance of other screening procedures, e.g. mammography $[4,32,33]$.

Some interesting observations emerged from this study as regards factors influencing patients' decision to participate in screening. Men three times more often declared themselves interested in screening endoscopy. However, according to the published outcomes of the national screening program in Poland, women participated in the program more often (women to men ratio $3: 2$ ), even though the program was addressed to both sexes equally. It seems that in the case of men, good intentions did not translate into action. Moreover, advanced lesions were more often found in men, putting men at higher risk than their female coevals [5]. Respondents suffering from diabetes mellitus (DM) declared their interest in screening endoscopy more often than respondents without diabetes (non-DM). This is an important observation, since diabetes is considered a risk factor for CRC. Furthermore, it has been 
shown that people with previous endoscopy considered undergoing screening tests twice as often. Probably fear of endoscopic procedures is lower in this group, which may generally encompass people who do not avoid doctors and have a more positive attitude towards all screening procedures.

Lower than high school education was associated with refusal to be screened, reflecting a logical conclusion that health awareness increases with the level of education. A three-fold greater readiness was observed in subjects with a family history of any cancer. Half of the subjects with a family history of CRC and $43 \%$ of respondents with relatives diagnosed with gastric cancer wanted to undergo screening endoscopy, but unfortunately these two groups were too small to prove any significance.

A disturbing tendency was observed in smokers and people abusing alcohol. Smokers declared almost twice as low readiness for screening, which may have its roots in their lifestyle associated with a more nihilistic attitude toward health. Similar conclusions were drawn by American authors, who found that smokers and alcohol abusers are less eager to participate in screening [34, 35]. These observations lead to the conclusion that a greater emphasis should be placed on the need to screen men, obese persons, smokers and alcohol abusers.

As mentioned above, after implementing the national colonoscopic screening program for colorectal cancer in Poland, an awareness campaign was launched in the public media. Nonetheless, in the period from 2002 to 2009 no significant increase in readiness for endoscopy screening was observed in our study sample. In different countries the percentage of people entering endoscopy screening programs ranges from $23 \%$ to $35 \%$ of the population to which the program is addressed $[33,36]$. In our study less than $20 \%$ of the target population was interested in screening. In fact, since the Polish CRC screening program excludes individuals with symptoms suggesting colorectal cancer, the number of patients eligible for the screening would be less than 13\% (at least 60 subjects would not be included - Figure 2).

\section{References}

1. Verdecchia A, Santaquilani $M$, Sant M. Survival for cancer patients in Europe. Ann Ist Super Sanita 2009; 45: 315-24.

2. Tables by population, regions, and sex for Western Europe, Northern Europe, Southern Europe, Central and Eastern Europe (except Russian Federation), incidence expressed as number of cases, for males and females for colon and rectum as compared to other cancer sites: the Globocan 2004 database. Lyon, France: International Agency for Research on cancer, (http:// www-dep.iarc.fr).
3. Segnan N, Senore C, Andreoni B, et al. SCORE3 Working Group-Italy. Comparing attendance and detection rate of colonoscopy with sigmoidoscopy and FIT for colorectal cancer screening. Gastroenterology 2007; 132: 2304-12.

4. Harewood GC, Murray F, Patchett S, et al. Assessment of colorectal cancer knowledge and patient attitudes towards screening: is Ireland ready to embrace colon cancer screening? Ir J Med Sci 2009; 178: 7-12.

5. Reguła J, Rupinski M, Kraszewska E, et al. Colonoscopy in colorectal-cancer screening for detection of advanced neoplasia. N Engl J Med 2006; 355: 1863-72.

6. Ziółkowski BA, Pacholec A, Kudlicka M, et al. Prevalence of abdominal symptoms in the Polish population. Prz Gastroenterol 2012; 7: 20-5.

7. Raport z wyników Narodowego Spisu Ludności i Mieszkań, Główny Urząd Statystyczny. 2002 http://www.stat.gov.pl/cps/ rde/xbcr/gus/PUBL_raport_z_wynikow_nsp_ludnosci_i_miesz kan_2002.pdf

8. Zdrojewski T, Bandosz P, Szpakowski P. Rozpowszechnienie głównych czynników ryzyka chorób układu sercowo-naczyniowego $w$ Polsce. Wyniki badania NATPOL PLUS. Kardiol Pol 2004; 64 (Suppl 4): S5-22.

9. Keighley MR, O'Morain C, Giacosa A, et al. United European Gastroenterology Federation Public Affairs Committee. Public awareness of risk factors and screening for colorectal cancer in Europe. Eur J Cancer Prev 2004; 13: 257-62.

10. Meineche-Schmidt V, Krag E. Dyspepsia in general practice in Denmark. A 1-year analysis of consulters in general practice. Scand J Prim Health Care 1998; 16: 216-21.

11. Bodger K, Daly MJ, Heatley RV. Prescribing patterns for dyspepsia in primary care: a prospective study of selected general practitioners. Aliment Pharmacol Ther 1996; 10: 889-95.

12. Bołdys H, Marek TA, Wanczura P, et al. Even young patients with no alarm symptoms should undergo endoscopy for earlier diagnosis of gastric cancer. Endoscopy 2003; 35: 61-7.

13. Maconi G, Kurihara H, Panizzo V. Gastric cancer in young patients with no alarm symptoms: focus on delay in diagnosis, stage of neoplasm and survival. Scand I Gastroenterol 2003; 38: 1249-55.

14. Fransen GA, Janssen MJ, Muris JW. Meta-analysis: the diagnostic value of alarm symptoms for upper gastrointestinal malignancy Aliment Pharmacol Ther 2004; 20: 1045-52.

15. Nikpour S, Asgari AA. Colonoscopic evaluation of minimal rectal bleeding in average-risk patients for colorectal cancer. World J Gastroenterol 2008; 14: 6536-40.

16. Talley NJ, Jones M. Self-reported rectal bleeding in a United States community: prevalence, risk factors, and health care seeking. Am J Gastroenterol 1998; 93: 2179-83.

17. Yusuf S, Hawken S, Ounpuu S, et al. INTERHEART Study Investigators. Effect of potentially modifiable risk factors associated with myocardial infarction in 52 countries (the INTERHEART study): case-control study. Lancet 2004; 364: 937-52.

18. Suerbaum S, Michetti P. Helicobacter pylori infection. N Engl J Med 2002; 347: 1175-86.

19. Yang P, Zhou Y, Chen B, et al. Overweight, obesity and gastric cancer risk: results from a meta-analysis of cohort studies. Eur J Cancer 2009; 45: 2867-73. 
20. Jee SH, Yun JE, Park EJ, et al. Body mass index and cancer risk in Korean men and women. Int J Cancer 2008; 123: 1892-6.

21. Huerta JM, Navarro C, Chirlaque MD, et al. Prospective study of physical activity and risk of primary adenocarcinomas of the oesophagus and stomach in the EPIC (European Prospective Investigation into Cancer and Nutrition) cohort. Cancer Causes Control 2010; 21: 657-69.

22. Yamaji $\mathrm{Y}$, Watabe $\mathrm{H}$, Yoshida $\mathrm{H}$, et al. High-risk population for gastric cancer development based on serum pepsinogen status and lifestyle factors. Helicobacter 2009; 14: 81-6.

23. Giacosa A, Franceschi S, La Vecchia C, et al. Energy intake, overweight, physical exercise and colorectal cancer risk. Eur J Cancer Prev 1999; 8 (Suppl 1): 53-60.

24. Anderson JC, Messina CR, Dakhllalah F, et al. Body mass index: a marker for significant colorectal neoplasia in a screening population. J Clin Gastroenterol 2007; 41: 285-90.

25. Yoshida I, Suzuki A, Vallee M, et al. Seruminsulin levels and the prevalence of adenomatous and hyperplastic polyps in the proximal colon. Clin Gastro Hepatol 2006; 4: 1225-31.

26. Chiu HM, Lin JT, Shun CT, et al. Association of metabolic syndrome with proximal and synchronous colorectal neoplasm. Clin Gastroenterol Hepatol 2007; 5: 221-9.

27. Anderson JC, Atam R, Alpern Z, et al. Prevalence of colorectal neoplasia in smokers. Am J Gastroenterol 2003; 98: 2777-83.

28. Lieberman DA, Prindiville S, Weiss DG, et al. Risk factors for advanced colonic neoplasia and hyperplastic polyps. JAMA 2003; 290: 2959-67.

29. Hannan LM, Jacobs EJ, Thun MJ. The association between cigarette smoking and risk of colorectal cancer in a large prospective cohort from the United States. Cancer Epidemiol Biomarkers Prev 2009; 18: 3362-7.

30. Parkin DM, Bray FI, Devesa SS. Cancer burden in the year 2000. The global picture. Eur J Cancer 2001; 37 (Suppl 8): S4-66.

31. Parkin DM, Bray F, Ferlay J, et al. Estimating the world cancer burden: Globocan 2000. Int I Cancer 2001; 94: 153-6.

32. Harewood GC, Wiersema MJ, Melton LJ 3rd. A prospective, controlled assessment of factors influencing acceptance of screening colonoscopy. Am J Gastroenterol 2002; 97: 3186-94.

33. Segnan N, Senore C, Andreoni B, et al. Comparing attendance and detection rate of colonoscopy with sigmoidoscopy and FIT for colorectal cancer screening. Gastroenterology 2007; 132: 2304-12.

34. Coups EJ, Manne, SL Meropol NJ, et al. Multiple behavioral risk factors for colorectal cancer and colorectal cancer screening status. Cancer Epidemiol Biomarkers Prev 2007; 16: 510-6.

35. Subramanian S, Amonkar MM, Hunt TL. Use of colonoscopy for colorectal cancer screening: evidence from the 2000 National Health Interview Survey. Cancer Epidemiol Biomarkers Prev 2005; 14: 409-16.

36. UK Flexible Sigmoidoscopy Screening Trial Investigators. Single flexible sigmoidoscopy screening to prevent colorectal cancer: baseline findings of a UK multicentre randomised trial. Lancet 2002; 359: 1291-300. 